\title{
Chinese and Foreign Sports Industry Development TFP Analysis and DEA Approach Applied Research
}

\author{
Changjun Zhang*
}

Institute of Physical Education, Yangtze University, Jingzhou 434000, Hubei, China

\begin{abstract}
TFP analysis was conducted on Chinese and foreign sports industry by applying DEA approaches to detect TFP fluctuation. The research highlighted the influence factors to analyse the overall TFP index description process from year the year 2010 to 2013. The results indicated that Puma, Adidas, and Nike experienced relatively rapid increase in TFP in these four years and the main factors that affected the Chinese sports product industry were observed to be investment in human resource, in research as well as in machinery and equipment.. Foreign business proportions and enterprises bearing increase in tax also have certain impacts on the TFP of sports industry. Finally, the paper also gives relative suggestions to provide theoretical basis for Chinese sports product industrial development.
\end{abstract}

Keywords: DEA model, Sports health, Sports industry, TFP analysis.

\section{INTRODUCTION}

Sports industry plays an important role in the field of sports. Improvement in people's living standards is of importance to enterprise development. Especially after the successful hosting of Beijing Olympic Games, sports product industry has experienced rapid development, therefore this research will contribute to the industrial development of Chinese sports products [1].

Regarding sports products industry research, former researchers such as Wei De-Xiang et al made many efforts, and achieved some results [2]. These researches attempted to list companies' operations, through analyzing nine Chinese and foreign sports goods companies and declared financial data from the year 2008 to 2010. Finally, overall comprehensive efficiency mean values were obtained showing a rising trend, in which technical progress showed incomparable effects. [3] Li Xun-Jin in his scientific research on Chinese and foreign sports targeted the functioning of domestic and foreign governments, funding sources, contents, sports research system and prospects of scientific researches on sports thereby making comparative analysis, and finally put forward relevant opinions [4].

The paper targeting hinese and foreign sports product industry provided detailed analysis and finally proposed that Chinese government should encourage international highend sports products development in China, promote scientific research on sports product, and form a perfect sports products service system for changing the international status of Chinese sports products [5].

*Address correspondence to this author at the Institute of Physical Education, Yangtze University, Jingzhou 434000, Hubei, China;

E-mail: ChangjunZhang002@163.com

\section{DEA MODEL ESTABLISHMENTS}

DEA model is a data envelopment analysis approach that uses the available model to obtain corresponding product frontier to evaluate DMU (decision unit) with its input and output. In DEA, the enterprises' relative efficiency is distributed between 0 and 1, with the enterprises' efficiency value in efficiency frontier being 1 . Its advantages are numerous such as: DEA can conduct actual value and target value efficiency analysis, sensitivity analysis and comparative analysis. In DEA, model weight is mainly generated according to data being free of human factor influence, and its unit has indeformable characteristics. To measure TFP development of Chinese and foreign sports products industry, the paper adopted Malmquist exponential equation set by Fare and others to establish its exponential models, whose basic form is:

$M_{0}\left(y^{t+1}, x^{t+1}, y^{t}, x^{t}\right)=\left[\left(\frac{d_{0}^{t}\left(x^{t+1}, y^{t+1}\right)}{d_{0}^{t}\left(x^{t}, y^{t}\right)}\right) \times\left(\frac{d_{0}^{t+1}\left(x^{t+1}, y^{t+1}\right)}{d_{0}^{t+1}\left(x^{t}, y^{t}\right)}\right)\right]^{\frac{1}{2}}$

In the above formula, product input and output amount of $\mathrm{t}+1$ period and $\mathrm{t}$ period are $\left(x^{t+1}, y^{t+1}\right)$ and $\left(x^{t}, y^{t}\right)$ respectively, and the $t$ period and the $t+1$ period distance functions are represented as $d_{0}^{t}$ and $d_{0}^{t+1}$ respectively. For the $i+1$ and the $i$ period output and input ratio geometric mean, if the value is less than 1 , then it implies that sports products industry is experiencing a decline while, if the value is above 1, then it implies that sports product TFP is increasing. Malmquist index can be divided into two kinds; one of them is technical progress index and the other is decomposable technical efficiency variability index. Technical variability index is responsible for the distance between product leading surface and effective leading surface. Specific conditions are as follows: 
Table 1. DEA index-based sports goods manufacturing industry factor system table.

\begin{tabular}{|c|c|c|}
\hline First Grade Factor & Second Grade Factor & Definition of Factors \\
\hline \hline \multirow{3}{*}{ Input indicator } & Main business cost & Represent economic resources consumption conditions in enterprises' operation \\
\cline { 2 - 3 } & Total assets & $\begin{array}{r}\text { Enterprises-controlled, monetary measurement-adapted, representative of } \\
\text { enterprises scale capital input conditions }\end{array}$ \\
\hline \multirow{3}{*}{ Output indicator } & Basic earnings share & One of comprehensive reflection of enterprises profitability indicators \\
\cline { 2 - 3 } & Income from main business & $\begin{array}{c}\text { Main business regular basic income, represents enterprises operational abun- } \\
\text { dant ability }\end{array}$ \\
\cline { 2 - 3 } & Net margin & $\begin{array}{c}\text { Comprehensive reflect enterprises operational final results, represents opera- } \\
\text { tional efficiency conditions }\end{array}$ \\
\cline { 2 - 3 } & Net assets income rate & Comprehensive reflect enterprises profitability, net margin owner's right \\
\hline
\end{tabular}

Table 2. Year 2010-2013 Chinese sports product industry overall TFP index and decomposition index table.

\begin{tabular}{|c|c|c|c|c|c|c|}
\hline Year & $\begin{array}{c}\text { Technical } \\
\text { Progress }\end{array}$ & Scale Efficiency & $\begin{array}{c}\text { Pure Technical } \\
\text { Efficiency }\end{array}$ & $\begin{array}{c}\text { Technical } \\
\text { Efficiency }\end{array}$ & $\begin{array}{c}\text { Total Factor } \\
\text { Productivity (TFP) }\end{array}$ & $\begin{array}{c}\text { TFP Growth } \\
\text { Rate (\%) }\end{array}$ \\
\hline \hline 2010 & 0.988 & 0.955 & 1.000 & 0.955 & 0.944 & -5.6 \\
\hline 2011 & 1.072 & 1.047 & 0.996 & 1.052 & 1.123 & 1.173 \\
\hline 2012 & 1.184 & 0.991 & 0.985 & 1.006 & 1.101 & 17.3 \\
\hline 2013 & 1.111 & 0.991 & 1.002 & 0.989 & 1.008 & 1.082 \\
\hline Mean value & 1.087 & 0.995 & 0.995 & 1.000 & 8.2 \\
\hline
\end{tabular}

$M_{0}\left(y^{t+1}, x^{t+1}, y^{t}, x^{t}\right)=\frac{d_{0}^{t+1}\left(x^{t+1}, y^{t+1}\right)}{d_{0}^{t}\left(x^{t}, y^{t}\right)} \times\left[\left(\frac{d_{0}^{t}\left(x^{t+1}, y^{t+1}\right)}{d_{0}^{t+1}\left(x^{t+1}, y^{t+1}\right)}\right) \times\left(\frac{d_{0}^{t}\left(x^{t}, y^{t}\right)}{d_{0}^{t+1}\left(x^{t}, y^{t}\right)}\right)\right]^{\frac{1}{2}}$

In the above formula, $\frac{d_{0}^{t+1}\left(x^{t+1}, y^{t+1}\right)}{d_{0}^{t}\left(x^{t}, y^{t}\right)}$ represents sports product technical efficiency variation function relations from $i+1$ to $i$, and the above right side $-\left(\frac{d_{0}^{t}\left(x^{t+1}, y^{t+1}\right)}{d_{0}^{t+1}\left(x^{t+1}, y^{t+1}\right)}\right) \times\left(\frac{d_{0}^{t}\left(x^{t}, y^{t}\right)}{d_{0}^{t+1}\left(x^{t}, y^{t}\right)}\right)_{-}^{-}$represents measured sports product industry development conditions from the $\mathrm{t}$ period to $\mathrm{t}+1$ period technical aspect.

In order to compare the TFP differences of Chinese and foreign sports products industry, the paper selected the TFP of sports product industry of three internationaly listed famous brands of nine countries as key points of research. The selected twelve brands yearly data reported that Chinese and foreign sports product industry's turnover is basically consistent.

Twelve kinds of international and state level famous enterprises were listed which highlighted consistent data. The paper selected output items and input items and all the indicators are shown in the following Table $\mathbf{1 .}$

According to all the factors, the paper analyzed the annual report of twelve sports companies from 2010 to 2013. After sorting out the data, all enterprises' input and output data were obtained related to all items, with

\section{CHINESE AND FOREIGN SPORTS PRODUCT IN- DUSTRY TFP EVALUATION}

Based on the year 2010 to 2013, sports industry's overall TFP index and decomposition index as well as individual TFP index and its corresponding decomposition index were verified step by step using, DEAP software to carry out objective evaluation.

The paper established a Chinese and foreign sports product's overall TFP index and corresponding decomposition dynamic table as shown in Table 2.

In order to more clearly show mutual relations, the study gave a bar figure as shown in Fig. (1).

Chinese and foreign sports product's overall dynamic decomposition table is shown in Table $\mathbf{3}$.

In order to more clearly show the relationship of the above indicators, the paper presented a bar figure as shown in Fig. (2).

Tables $\mathbf{2}$ and $\mathbf{3}$ provide Chinese and foreign sports product industry's overall TFP index and decomposition index with dynamic situations from 2010 to 2013 of four years. Based on this data, the paper analyzed Chinese and foreign sports product industry's technical progress, scale efficiency, TFP, technical efficiency and other aspects.

In real production, foreign technical efficiency has not shown its technical potentials and resourceful utilization. It mainly suffers from the influence of pure technical efficiency index, while in the domestic enetrprises four 


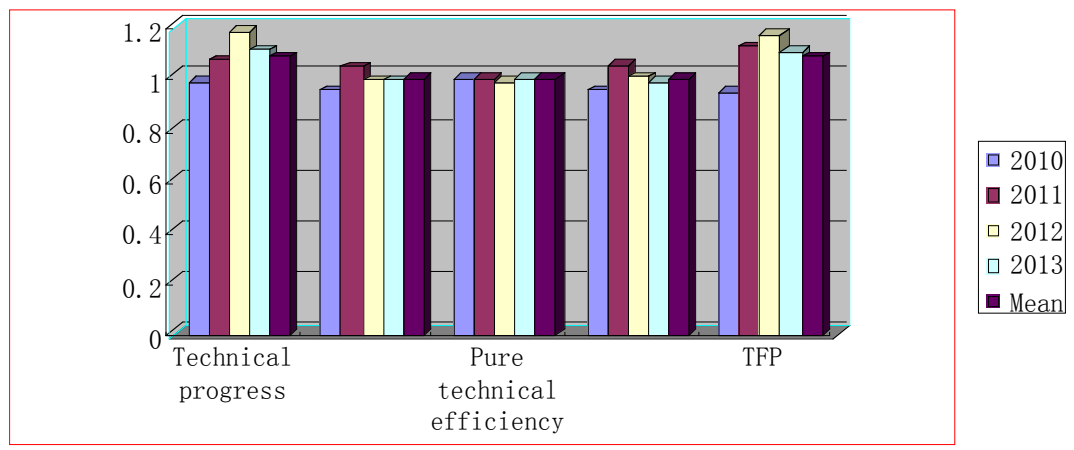

Fig. (1). 2010-2013 China sporting goods industry as a whole decompose TFP index map.

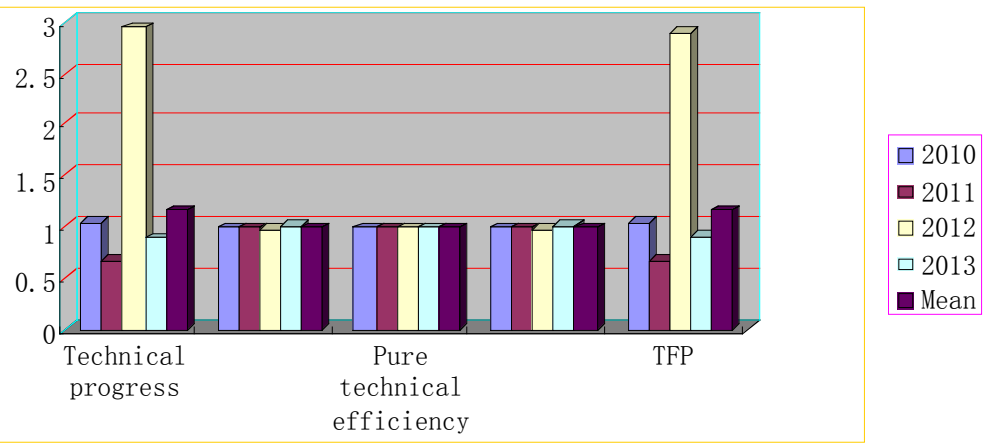

Fig. (2). 2010-2013 overall foreign sporting goods industry exploded TFP index map.

Table 3. Year 2010-2013 Chinese and foreign sports product industry overall TFP index and decomposition.

\begin{tabular}{|c|c|c|c|c|c|c|}
\hline Year & $\begin{array}{c}\text { Technical } \\
\text { Progress }\end{array}$ & Scale Efficiency & $\begin{array}{c}\text { Pure Technical } \\
\text { Efficiency }\end{array}$ & $\begin{array}{c}\text { Technical } \\
\text { Efficiency }\end{array}$ & $\begin{array}{c}\text { Total Factor } \\
\text { Productivity (TFP) }\end{array}$ & $\begin{array}{c}\text { TFP Growth } \\
\text { Rate (\%) }\end{array}$ \\
\hline \hline 2010 & 1.047 & 1.002 & 1.000 & 1.002 & 1.049 & 4.9 \\
\hline 2011 & 0.682 & 0.999 & 1.000 & 0.999 & 0.681 & -31.9 \\
\hline 2012 & 2.958 & 0.984 & 1.000 & 0.984 & 1.912 & 0.913 \\
\hline 2013 & 0.898 & 1.017 & 1.000 & 1.017 & 1.174 & -8.7 \\
\hline Mean value & 1.173 & 1.001 & 1.000 & 1.001 & 17.4 \\
\hline
\end{tabular}

years' comparison is not ideal in pure techniques that shows negative growth rate $t$ leading to technical efficiency reduction.

Based on the above analysis results, domestic powerful enterprises have started focusing on relevant problems discussed in the research. For instance, Li Ning company established a research and development center, Anta established a sport biomechanics laboratory, and 361 companies have also developed research and development center, human engineering laboratory and product laboratory. But China has still not reached to the level of foreign countries due to limited technical developments.

\section{CHINESE AND FOREIGN SPORTS PRODUCT IN- DUSTRY TFP INDIVIDUALS AND DECOMPOSI- TION INDEX EVALUATION}

In the analysis, the paper listed four years' TFP of seven sports product companies and corresponding decomposition index with dynamic situations as shown in Table 4.
From the above Table 4, it is clear that TFP of Chinese sports product industry in 2011 was high , especially for 361 , $\mathrm{X}$-step international holdings and Anta sports, which experienced a boom due to the impact of international market in 2011, while domestic and overseas sports product industry experienced a downfall. From the table, it can also be seen that since 2011, technical input and technical progress led to increase 361 and X-step international holdings TFP, while domestic reduction in Anta and Li Ning due to extrusion of TFP storage volume. Foreign sports products industry, due to economic recovery of America and other developed countries, like Nike, experienced a decline while Puma and Adidas, due to economic advancement in Germany and other countries, experienced TFP growth of above $20 \%$.

The paper compared Chinese and foreign sports product industry TFP not just for testing the decomposition index but mainly for examining its influence factors to make Chinese sports product industry play a positive role in future 
Table 4. Year 2010-2013 Chinese and foreign sports product listed companies TFP decomposition index table.

\begin{tabular}{|c|c|c|c|c|c|c|c|}
\hline Company Name & Year & $\begin{array}{l}\text { Technical } \\
\text { Progress }\end{array}$ & $\begin{array}{l}\text { Technical } \\
\text { Efficiency }\end{array}$ & $\begin{array}{c}\text { Pure Technical } \\
\text { Efficiency }\end{array}$ & Scale Efficiency & TFP & $\begin{array}{c}\text { TFP Growth } \\
\text { Rate }(\%)\end{array}$ \\
\hline \multirow{5}{*}{ Li Ning } & 2010 & 0.939 & 0.991 & 1.000 & 0.991 & 0.959 & -4.1 \\
\hline & 2011 & 0.979 & 1.116 & 1.000 & 1.116 & 1.092 & 9.2 \\
\hline & 2012 & 0.964 & 1.006 & 1.000 & 1.006 & 0.970 & -3 \\
\hline & 2013 & 0.886 & 1.000 & 1.000 & 1.000 & 0.886 & -11.4 \\
\hline & Mean value & 0.887 & 1.000 & 1.000 & 1.000 & 0.887 & -11.3 \\
\hline \multirow{5}{*}{361 degree } & 2010 & 1.183 & 1.000 & 1.000 & 1.000 & 1.183 & 18.3 \\
\hline & 2011 & 0.910 & 0.972 & 1.000 & 0.972 & 0.993 & -0.7 \\
\hline & 2012 & 0.957 & 1.028 & 1.000 & 1.028 & 0.984 & -1.6 \\
\hline & 2013 & 0.881 & 1.000 & 1.000 & 1.000 & 0.881 & -11.9 \\
\hline & Mean value & 0.983 & 1.000 & 1.000 & 1.000 & 0.983 & -1.7 \\
\hline \multirow{5}{*}{$\begin{array}{l}\text { X-step internation- } \\
\text { al holdings }\end{array}$} & 2010 & 1.384 & 1.036 & 1.025 & 1.011 & 1.434 & 43.4 \\
\hline & 2011 & 0.745 & 1.003 & 1.000 & 1.003 & 0.747 & -25.3 \\
\hline & 2012 & 1.816 & 1.000 & 1.000 & 1.000 & 1.816 & 81.6 \\
\hline & 2013 & 0.904 & 0.855 & 0.865 & 0.989 & 0.773 & -22.7 \\
\hline & Mean value & 1.205 & 0.985 & 1.000 & 0.985 & 1.187 & 18.7 \\
\hline \multirow{5}{*}{ Anta sports } & 2010 & 0.606 & 0.879 & 0.980 & 0.896 & 0.533 & -46.7 \\
\hline & 2011 & 0.913 & 1.093 & 0.994 & 1.100 & 0.998 & -0.2 \\
\hline & 2012 & 1.637 & 1.041 & 1.027 & 1.014 & 1.704 & 70.4 \\
\hline & 2013 & 1.850 & 1.000 & 1.000 & 1.000 & 1.850 & 85 \\
\hline & Mean value & 1.138 & 1.000 & 1.000 & 1.000 & 1.138 & 13.8 \\
\hline \multirow{5}{*}{ Puma } & 2010 & 0.919 & 1.000 & 1.000 & 1.000 & 0.919 & -8.1 \\
\hline & 2011 & 0.832 & 0.998 & 1.000 & 0.998 & 0.830 & -17 \\
\hline & 2012 & 1.132 & 0.963 & 1.000 & 0.963 & 1.090 & 9 \\
\hline & 2013 & 0.953 & 1.041 & 1.000 & 1.041 & 0.991 & -0.9 \\
\hline & Mean value & 0.889 & 1.000 & 1.000 & 1.000 & 0.889 & -11.1 \\
\hline \multirow{5}{*}{ Adidas } & 2010 & 1.017 & 1.007 & 1.000 & 1.007 & 1.024 & 2.4 \\
\hline & 2011 & 0.936 & 1.000 & 1.000 & 1.000 & 0.936 & -6.4 \\
\hline & 2012 & 1.542 & 1.000 & 1.000 & 1.000 & 1.542 & 54.2 \\
\hline & 2013 & 0.886 & 1.000 & 1.000 & 1.000 & 0.886 & -11.4 \\
\hline & Mean value & 1.296 & 1.002 & 1.000 & 1.002 & 1.299 & 29.9 \\
\hline \multirow{5}{*}{ Nike } & 2010 & 1.228 & 1.000 & 1.000 & 1.000 & 1.228 & 22.8 \\
\hline & 2011 & 0.989 & 1.000 & 1.000 & 1.000 & 0.789 & -1.1 \\
\hline & 2012 & 1.284 & 0.991 & 1.000 & 0.991 & 1.214 & 21.4 \\
\hline & 2013 & 0.964 & 1.009 & 1.000 & 1.009 & 0.973 & -2.7 \\
\hline & Mean value & 1.201 & 1.000 & 1.000 & 1.000 & 1.201 & 20.1 \\
\hline
\end{tabular}


Table 5. TFP technical efficiency and technical progress influence factors analysis table.

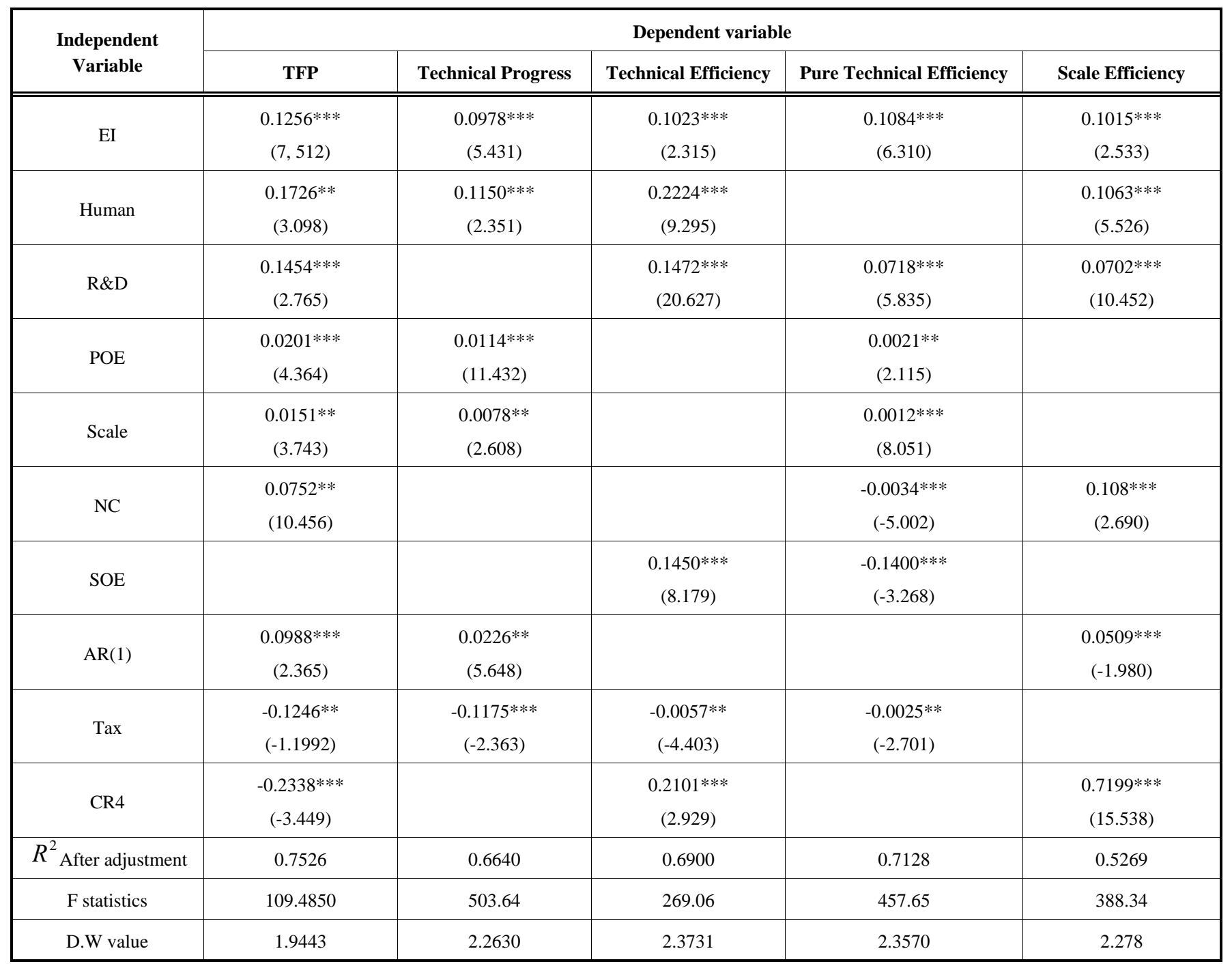

*It represents to arrive at significant correlation in the level 0.01 ; **It represents to arrive at significant correlation in the level 0.05 ; ***It represents to arrive at significant correlation in the level 0.10;

development to improve Chinese sports product industry's TFP. According to former researches, the paper adopted various influence factors, which mainly include enterprise tax burden, enterprise concentration ratio, new product ratio, average size of enterprises, domestic business ratio, foreign business ratio, human capital, investment in research and development as well as investment in mechanical equipment. For possible hidden serial correlation and heteroscedasticity problems in panelling data, the paper employed stata software's least square method to analyze, and obtain results as shown in Table $\mathbf{5}$.

From the above Table 5, it was observed that:

1) Enterprise scale efficiency is positively related to enterprise scale and enterprise concentration ratio, from which the most important influence factor is the enterprise scale. However, enterprise scale efficiency is positively related to enterprise's human resource, investment in research and development, as well as investment in mechanical equipment;
2) Enterprises shows a positive relation of human resource and equipment investment. and is the main influence factor, enterprise new product investment is bigger and then pure technical efficiency will be lower, while enterprise scale becomes bigger than pure technical efficiency accordingly will be lower. Therefore it proves the causes for current China sports product industry constantly appear new products, but pure technical efficiency is still low;

3) Enterprise technical efficiency show a kind of positive relations with mechanical equipment, human capital investment, research and development investment and new product ratio, from which minimum influence belongs to enterprise concentration ratio and enterprise scale, while the maximum influence belongs to scientific research investment, therefore it can prove enterprise scale and enterprise technical efficiency are not in a proportional relationship, it is mainly up to technical factors;

4) Investment in research and development as well as in mechanical equipment are important factors to drive 
technical progress, on which the impacts of human resource are not obvious. It is because that the relative contribution rate of Chinese and foreign business ratios is greater in technical progress. In addition, increased tax will play an important role in enterprise's technical development.

5) Mechanical equipments research and development as well as human resource driving TFP are the greatest influencing factors of an enterprise, having the highest impact on TFP. TFP growth and improvement in domestic business contribution rate are obviously lower than that in the overseas, while sports enterprise's contribution to TFP is adequate, implying that the larger the sports product industry, the larger the TFP.

\section{CONCLUSION}

By analysing the overall TFP index description from 2010 to 2013 of Chinese and foreign sports product industry, and combining the data shown in the tables, it can be observed that Puma, Adidas and Nike as overseas sports product industries experienced rapid TFP development in these four years, with an average growth rate of $17 \%$. Meanwhile, although overall sports product industry experienced development, but compared to overseas, its overall development has been slower, from year 2010 to 2013 . Overseas sports product industry's technical efficiency index increased by 0.1 percentage, and technical progress showed $17 \%$ growth rate, which is mainly because overseas techniques are still more advanced than domestic. Domestic sports products industry's technical progress rate remained $8 \%$, because technical efficiency did not increase but dropped, and the $8 \%$ growth rate in TFP was actually lower than the overseas.

The main influencing factors affecting Chinese sports products industry are investment in human resources, investment in research and development and investment in mechanical equipment, and the ones positively contributing to Chinese sports product industry development are mainly regional concentration and production scale. Foreign business ratio, and increased tax burden on enterprise still have certain impact on the TFP of sports products industry.
Based on the conclusion, the paper put forward following suggestions in order to modify Chinese sports product industry's international status. China's government should play a major role in this process. It should encourage the development of international high-end sports products in China, and introduce sports product scientific research development.. It can introduce advanced techniques and equipment as well as management staff and scientific researchers by taking assistance from famous foreign brands enterprises and should also develop relevant industries by optimizing development environment, to establish a perfect sports products service system.

\section{CONFLICT OF INTEREST}

The author confirms that this article content has no conflict of interest.

\section{ACKNOWLEDGEMENTS}

Declared none.

\section{REFERENCES}

[1] P. Chen, Z. Qin, Y. Yin, and C. Xia, "Correlation analysis of current situation of regional athletics sports development and society population structure in China," Journal of Beijing Sport University, vol. 30, no. 12, pp. 1610-1613, 2007.

[2] H. Li, H. Xue, and W. Feng, "Sociological analysis of comparison of chinese population with the sports population of chinese," Journal of Xi'an Institute of Physical Education, vol. 24, no. 4, pp. 25-28, 2007.

[3] Z. Miao, and C. Qin, "Sociological analysis of contemporary Chinese sports population structures," Journal of Physical Education, vol. 13, no. 1, pp. 119-121, 2006.

[4] H. Xiao, Z. Weng, and Y. Chen, "Basic characteristics of social and sports population structures of contemporary China," Journal of Shanghai Physical Education Institute, vol. 29, no. 2, pp. 10- 14, 2005.

[5] J. Xue, and J. Wang, "Analysis on development level of competitive sports of eastern china in the "eleventh five-year" Period," Bulletin of Sport Science \& Technology, vol. 19, no. 4, pp. 57-59, 2011.

Received: June 10, 2015

This is an open access article licensed under the terms of the (https://creativecommons.org/licenses/by/4.0/legalcode), which permits unrestricted, noncommercial use, distribution and reproduction in any medium, provided the work is properly cited. 